Article

\title{
Does Adoption of Management Standards Deliver Efficiency Gain in Firms' Pursuit of Sustainability Performance? An Empirical Investigation of Chinese Manufacturing Firms
}

\author{
Xiaoling Wang ${ }^{1, *, \dagger}$, Haiying Lin ${ }^{2, \dagger}$ and Olaf Weber ${ }^{2}$ \\ 1 School of Economics and Management, University of Science and Technology Beijing, 30 Xueyuan Road, \\ Haidian District, Beijing 100083, China \\ 2 School of Environment, Enterprise \& Development, University of Waterloo, 200 University Avenue West, \\ Waterloo, ON N2L 3G1, Canada; h45lin@uwaterloo.ca (H.L.); oweber@uwaterloo.ca (O.W.) \\ * Correspondence: wangxiaoling@ustb.edu.cn; Tel.: +86-10-623-345-98 \\ + These authors contributed equally to this work.
}

Academic Editor: Giuseppe Ioppolo

Received: 29 February 2016; Accepted: 13 July 2016; Published: 20 July 2016

\begin{abstract}
Building on longitudinal data from 73 Chinese manufacturing firms during 2009-2012, we assess whether and how firms gain higher efficiency in achieving their sustainability goals by adopting management practice standards (ISO 9001, ISO 14001, and/or OHSAS 18001). We propose four pathways for firms to gain sustainability efficiency in their certification journey: participation, qualitative integration, quantitative expansion, and temporal accumulation. Our results confirm that firms certifying management standards gain higher efficiency in pursuing their sustainability goals than firms without these standards. We also find some support for increased efficiency effect in firms with diverse management systems over firms with only a single certificate in 2011. Finally, our results highlight the experiential and temporal accumulation effect of such efficiency gains, that is, firms with prior certification experience or having a longer certification history demonstrate higher efficiency gains in pursuing their sustainability goals.
\end{abstract}

Keywords: ISO 9001; ISO 14001; OHSAS 18001; dynamic capability; corporate sustainability efficiency

\section{Introduction}

In recent years, certifiable standards of management practices, such as ISO 9001, ISO 14001, and OHSAS 18001, have been increasingly adopted by businesses around the world. These standards focus on the implementation of control systems, the central purpose of which is to manage corporate environmental and social responsibility (CSR) [1,2]. Many studies have been conducted to assess firms' subsequent socio-ecological performance, that is, whether firms actually improve their environmental, quality, and social (health) control performance as a result of their decision to certify under such management system standards [3].

A heated debate has been conducted in the literature as to whether these standards lead to authentic sustainable development outcomes [2]. Proponents highlight the evidence that ISO 14001 is significantly associated with waste reduction and emissions mitigation [4]. Opponents, however, question whether these certificates lead to genuine sustainable development performance [5,6], in part because these standards' focus on processes rather than firms' actual performance [7], and in part due to the increased organizational complexity and operating costs related to the certification and implementation process [8]. 
The decision to certify under these programs is essentially an economic and/or an efficiency consideration because of the associated expenses. Certifications require participating firms to implement in-house management systems before receiving an initial audit and require subsequent annual recertification audits to maintain the status [9]. For example, adopting a formal environmental management system (EMS) and certifying under ISO 14001 typically costs between \$270 and \$1370 USD per employee every three years [10], thus resulting in substantial expense and commitment to participants. Given intense stakeholder scrutiny over corporate environmental and social operations, and increased costs of implementing and maintaining these management standards, certified organizations may lack the motivation to fully implement these standards unless there is noticeable financial or efficiency gain $[7,8]$.

It is, therefore, critical to business decision-making to demonstrate whether certified firms improve their efficiency in pursuing corporate sustainability compared to firms without certifications. Despite the importance of this topic, prior management studies tend to assess certified firms' financial outcomes rather than sustainability and performance efficiency improvements $[6,11,12]$. Prior studies also tend to assess each standard (either ISO 9001, or ISO 14001, or OHSAS 18001) individually, and rarely combine them in an integrative assessment. These studies rarely integrate triple-bottom-lines (both financial and social-ecological aspects) into their evaluations, thus lacking a holistic assessment of whether certified firms achieve higher efficiency in achieving their sustainability goals than firms without certifications. Further, it also remains ambiguous regarding how firms continue to accumulate their efficiency gain in their pursuit of corporate sustainability.

The objective of this study is to address this gap by analyzing the impacts of certification on firms' efficiency in pursuing corporate sustainability goals. We explore whether firms with certified management system standards obtain higher efficiency gain than non-certified firms, and via what paths firms accumulate their efficiency gain through the journey. Our definition of corporate sustainability efficiency (CSE) reflects the conventional definition of efficiency as creating a certain output with as less input as possible. It is the efficiency in achieving given sustainability performance (financial, environmental, and social) with as few inputs (labor, financial capital, and operational expenses) as possible.

This study advances the management certification literature in three ways. First, instead of assessing the performance of management standard certification from a single financial or environmental (social) aspect, we integrate the triple-bottom-line goals and assess the performance of certification from a dynamic capacity aspect.

Second, using longitudinal data of 73 Chinese-listed manufacturing firms from 2009-2012, we empirically assess the certified firms' sustainability efficiency gain from four pathwaysparticipation, qualitative integration, quantitative expansion, and temporal accumulation. These insights contribute to the management discourse by highlighting how firms qualitatively, quantitatively, experientially, and temporally accumulate more efficiency gains through management certification.

Third, this study expands the literature debate regarding the efficiency of management standards in delivering sustainable performance outcomes. Our proposed efficiency accumulation pathways take a dynamic process and learning perspective, moving the literature dialogue from "whether" (whether certification delivers actual sustainability performance) to "how" (how firms build up the capacity to improve sustainability efficiency in their certification journey). Our results have important managerial implications to Chinese manufacturing firms, and beyond, as certification practices for sustainability have been increasingly adopted by organizations across the world, especially in emerging economies like China. 


\section{Theory and Hypothesis Development}

\subsection{Literature Review}

\subsubsection{Management Practice Standard Certifications}

International management systems, such as the International Organization for Standardization 9001 (ISO 9001), the International Organization for Standardization 14001 (ISO 14001), and the Occupational Health and Safety Assessment Series 18001 (OHSAS 18001), have been widely promoted specifically to help firms improve their quality, environmental, and social performance [13,14]. ISO 9001 is a certified Quality Management System founded in 1991 to help establish a process-based system for organizations to achieve and sustain the quality of a product or service. Through the promotion of Total Quality Management (TQM), it enhances production efficiency and customer royalty, thus enhancing competitive advantage of the certified firms. We, therefore, suggest ISO9001 to reflect economic and financial performance of certified firms. ISO 14001, issued in 1996, is a certified Environmental Management System (EMS) that enables organizations to manage processes to continually reduce their impact on the natural environment. OHSAS 18001, first published in 1999, provides organizations a framework for implementing a system for occupational health and safety performance. It protects employees' welfare and, therefore, targets the social dimension of sustainability. We did not include ISO 26000 in the assessment as this standard, similar to the United Nation Global Compact, is not certifiable.

Internally, these management systems, such as ISO 9001, ISO 14001, and OHSAS 18001, provide valuable management tools to business, and firms learn to collect, diagnosis, monitor, and report information related to employee training, management, and internal control. Externally, the documentation and procedural standards enable firms to report and signal their sustainability performance to stakeholders, and help reduce the information asymmetry plaguing international and domestic trade [15]. Moreover, while these various management system standards focus on different performance aspects, they share similar management techniques and a common underlying theoretical principle based on a Plan-Do-Check-Act (PDCA) cycle. This cycle enables participating firms to conduct continual improvements in their quality, environmental, and social responsibilities. Their common PDCA structure makes these diverse standards compatible and allows them to be integrated to achieve higher efficiency [3].

\subsubsection{Certification Performance Assessment}

Individual studies in the literature have independently assessed each certification standard's effectiveness from a socio-ecological or financial aspect. From a financial aspect, advocates of certification assert that both ISO 9001 and ISO 14001 have contributed to greater customer satisfaction by leading to the development of greener products and higher quality service [16,17]. They suggest that ISO certifications provide greater quality awareness, enhanced employee productivity, better quality control, improved internal auditing, and clearer managerial responsibility, thus providing certified firms with financial advantages such as increased revenue, reduced costs, higher profits, and increased market competition [18-20].

Nevertheless, others find no financial performance benefits related to certification [21-23]. Instead they indicate that ISO certifications may lead to low operational efficiency of business since it is still a risk-increasing activity as managers need to take into account all stakeholders' requirements. Some scholars suggest that certifications fail to help increase firms' performance [3], or that the benefits of process management practices dissipate in an industry as the majority of firms adopt similar techniques [24]. Even though certain improvements in operational efficiency can be derived from ISO 9000 adoption, these benefits do not translate into financial performance improvements [25]. Benefits of ISO adoption may also be moderated by firm-specific technological coherence in some cases [24].

Relative to ISO 14001 and its impact on organizations' environmental performance, some studies show positive corporate environmental improvements [26,27]. For instance, by using the structural 
equation model to analyze questionnaire data collected from ISO 14001 registrants, Rao and Hamner found significant reductions in waste production and resource usage within the sampled firms [28]. Conversely, other questioned the effectiveness of the standards and their impacts on environmental outcome [6,29]. Thus, it is not clear yet whether ISO 14001 adoption is associated with improved environmental performance [12].

Relative to OHSAS 18001, some suggest it helps firms eliminate or minimize organizational health and safety risks to employees and other interested parties and, thus, is considered to be targeting the social dimension of sustainability. Robson discussed the positive effects of OHSAS implementation, including a better safety climate, a decrease in injury rates, a decrease in disability-related costs, and an increase in work-place productivity [30]. However, few empirical studies has been conducted to assess the social performance in a narrow sense (i.e., social justice and equity) due to the lack of consensus on relevant criteria [31].

Therefore, previous studies have produced broadly diverse and fragmented financial and social-ecological performance assessments of different management standards. These previous assessments show varied performance outcomes ranging from extraordinary successes to an unproductive "cost of doing business" [11]. The literature lacks an integrative assessment of whether certified firms gain higher efficiency in their pursuit of corporate sustainability (including both financial, environmental, and socio-ecological aspects) than non-certified ones, and how these firms build up efficiency gain post-certification.

\subsection{Dynamic Capability Theory}

The theoretical approach for our research is dynamic capability theory. This theory refers to "a firm's ability to integrate, build, and reconfigure internal and external competences to address rapidly changing environments" [32]. It focuses on the alteration and integration of acquired resources to recreate and regenerate new value [33]. Through continuous learning and optimization in response to, or even shaping, a turbulent environment, corporations may gain dynamic capabilities that enable them to sustain their competitive advantage [34]. Firms' adoption and integration of management standards is a prime example of the application and development of dynamic capabilities theory [35]. This theoretical perspective allows us to illustrate how firms' leverage certification processes to accumulate resources and learning when dealing with quality, environmental, and social issues.

The implementation and maintenance of management standards is a multi-level, multi-dimensional, and multi-sectorial dynamic process that must be assimilated into the administrative, entrepreneurial, and technical dimensions of a firm [36]. These standards follow the "Plan-Do-Check-Act (PDCA)" cycle, which enables participating firms to engage in a dynamic sustainability improvement process [37]. During the engagement process, the implementation of these varied management standards can adapt to various settings and objectives in different organizations, which may facilitate the integration of resources across different systems and enable diverse learning across different functional units and departments within an organization. Through the acquisition, reconfiguration, and integration of organizational, human, information, knowledge, technological, and managerial resources, a certified firm may develop dynamic capability enabling them to reach higher efficiency in overall sustainability improvement than firms without any certifications. Post-certification, firms may further enhance their efficiency gain through the effects of multiple certifications and their experiences in certifying.

\subsection{Hypotheses Development}

The following hypotheses are proposed based on the dynamic capability theory to explain how certification provide a learning and capacity development platform for firms to improve efficiency in handling sustainability issues. Such efficiency can be generated and enhanced if firms go through the initial participation hurdle, conduct trial-and-errors in different certification types, scale up the volume 
of certifications, accumulate certification experience, and accumulate capacity over time. The following section will explain the hypotheses development in detail.

We suggest that firms with certified management standards tend to gain higher efficiency in their pursuit of sustainability than firms without such certifications for the following reasons. The first reason relates to firms' chances of resource integration and continual social and environmental improvement. Implementing and certifying the first management standard remains a big hurdle for many firms. If firms successfully mobilize resources to develop their initial management standard system and infrastructure, they may obtain a continuous learning opportunity through which the organization systematically generates and modifies its operating routines in pursuit of improved effectiveness [38]. During the implementation process, a certified firm may gradually develop capacity to efficiently pursue quality, environmental, and social goals, usually resulting in significant cost-savings and continuous advancement.

The second reason relates to firms' chances to improve stakeholder relationships and engagement. A certified organization is required to update and innovate its business procedures and strategies to comply with the requirements and expectations of both internal and external stakeholders. Involvement in a certification process enables firms to strengthen awareness of their existing environmental and social activities and impacts, as well as their responsibility to diverse stakeholders [39]. Relative to internal stakeholders, the certification process requires a high employee engagement level, which enables organizations, especially managers and executives, to pay closer attention to its human resources and explore means to enhance employee engagement, a key asset for achieving process success [40]. The intensive employee training and human resource governance associated with certification may contribute to a firm's continual competitiveness and enhanced capability to deal with internal social issues more effectively [41].

Additionally, the certification process requires firms to accommodate external stakeholders' requirements, as well as compile and report social and environmental performance data to external stakeholders following standard formats and procedures. During this process, certified firms may grow their transparency and authenticity in voluntary reporting, thus developing stronger relationships with key external stakeholders, such as customers, employees, suppliers, governments, and communities $[3,9,42]$. Such tacit assets enhance brand value and reputation, from which may be derived capability for certified firms to pursue sustainability with higher efficiency $[43,44]$.

The third reason relates to improvements in organizational structure and culture. The certification process provides a dynamic mechanism or system that allows firms to continually adapt to, become embedded in, or gradually modify in their own culture and structure to facilitate a successful implementation. During a system's implementation process, an organizational structure and culture may become more coordinated and harmonized such that processes can be integrated smoothly and effectively. As such, a certified management system may facilitate the modification or transformation of organizational structures and culture in a way that enhance firms' likelihood to enhance their CSE.

In summary, certified firms may gain greater efficiency in pursuing sustainability goals than non-certified firms because of their gained access to process-focused sustainability practices, and their need to conform to routines and procedures that engage internal employees and strengthen external stakeholder relationships. This, we posit, may augment firms' dynamic capabilities to tackle quality, social, and environmental improvements more effectively.

\section{Hypothesis 1: Certified firms obtain greater efficiency in their pursuit of sustainability than} non-certified firms.

In response to diverse stakeholders, firms may decide to adopt more than one management system. When two or more management systems with different functions are implemented by an organization, synergism may occur when the varied systems are combined and integrated within that organization to collectively address corporate social and environmental issues. We refer to this pathway of efficiency gain (in pursuit of sustainability) as "qualitative combination". 
Some studies demonstrate that over time firms show an increased tendency to integrate their management standards rather than keeping them separated, despite the existence challenges, such as the complexity of internal management and increased management costs [45]. It is often easier and appealing for organizations with existing certification(s) to adopt and assimilate another related management systems as such combination may improve implementation efficiency and enhance dynamic capability building. For instance, ISO 9001 often leads to improvements that allow further certification under ISO 140001 [46]. Firms that integrate varied certifications may gain higher efficiency since overall costs of system adoption and system management can be lower as firms develop practices that integrate and combine resources [47].

Specifically, the varied certifications can be bundled and integrated in a way to derive synergies and greater benefits, including reduced paperwork and training, avoided duplication of effort, simplified certification processes, improved learning processes, and increased organizational efficiency $[48,49]$. Evidence also shows that management system combination and integration can enhance corporate image and improve financial and operational performance [50]. Firms may deliver better products and services when their organizational systems can be integrated and focused on same targets [51]. Such integrated management systems may allow a firm to improve customer satisfaction while also increasing product innovation [49]. Due to the potential benefits associated with the combination of varied management standards, we propose that:

\section{Hypothesis 2: Firms with a variety of certification standards obtain greater efficiency in their pursuit of sustainability than firms with homogeneous certification standard.}

In addition to qualitative combination, firms may accumulate and scale up their dynamic capacity and obtain greater efficiency in pursing sustainability by expanding their total numbers of certifications, for instance through re-certification of a same management system in the following years or through certifying different facilities with the same management system. We refer to this pathway of efficiency gain (in pursuit of sustainability) as "quantitative expansion. It is conceptually distinct from qualitative combination as it focuses on scaling up the experience of a single type of certification throughout the organization rather than exploring the combination of different management systems.

Certifying for a large number of certifications across different facilities and branches may allow firms to replicate their matured practices at multiple facilities and branches within an organization, thus scaling up the efficiency gain in their pursuit of sustainability goals over the entire firm. Moreover, incremental improvements may occur as increasing numbers of certifications are implemented on multiple levels within an organization, ranging from the top "management" (i.e., strategic synergetic) level to the second "resource" (i.e., structural, and cultural synergetic) level, and the third "operational" (i.e., documentation synergetic) level [40]. Advantages generated from the synergetic effects of numerous certifications within an organization can translate into greater efficiency gain (in their pursuit of sustainability) associated with economies of scale and decreased operational costs [52]. We, therefore, posit that:

\section{Hypothesis 3: Firms with larger number of certifications obtain greater efficiency in their pursuit of sustainability than firms with fewer certifications.}

Since management systems are process-focused, it takes time for the various features of a new management system to be assimilated into a specific organisation. It also takes time and experience for certified firms to extract the efficiency outcome associated with their qualitative combination of diverse management standards, and/or quantitative expansion of a certain management standard to a larger scale. We refer to this pathway of efficiency gain (in pursuit of sustainability) as "temporal accumulation" [24].

Specifically, a firm's environment is constantly changing during the course of certification and implementation [53]. Temporal accumulation may stimulate certified firms' dynamic capacity to improve efficiency through "learning by doing" [54]. In this sense, we suggest that a firm's experience 
with certification enhances its ability to extract more sustainable development outcomes out of the current certification program. Because these firms have evaluated a diverse set of environmental concerns in their previous certification, they may have tested different approaches in dealing with a varied array of regulatory, technological, human, social (employee), and political factors involved in the certification process. This prior experience makes firms more aware of different aspects of its current certification program, enhances a firm's ability to communicate with internal and external stakeholders in the environmental and social domain, and allows firms to steer new sustainable developments more effectively-all of which are important capabilities to enhance efficiency in firms' pursuit of sustainability through the certification program. On this basis, we suggest:

\section{Hypothesis 4a: Firms with prior certification experience obtain greater efficiency in their pursuit of sustainability than firms without the experience.}

Regarding the temporal effect of firms' certification history, we assume that firms' certification history may have a negative effect to CSE initially but gradually demonstrate a positive effect to firms' efficiency gain in the long run. The first reason for this relates to the adoption of different versions of certification, which may lead to variances in efficiency gain. For example, the older versions of management systems (such as ISO 9001:1994 or 2000 version) were not perfectly designed when first released. Management systems have undergone major modifications and improvements in recent years. These modifications and the addition of updated management systems (i.e., ISO 14001, OHSAS 18001, and, in particular, ISO 9001:2008 version) have greatly enhanced their compatibility and effectiveness [42]. Therefore, firms with longer certification histories may have developed their operational infrastructure based on a less effective version of certification, resulting in diminished effects in their gained efficiency during initial years.

The second reason relates to enhanced organizational complexity and cost during their initial years of implantation. Over the long run, however, the ongoing expenses of standard operation (marginal cost) are expected to decrease gradually. Meanwhile, the effectiveness of these management systems is likely to continually improve with time. As such, there are long-term benefits associated with management system certification. Longer exposure to management systems allows firms to better assimilate knowledge and gradually develop capacity to improve efficiency in firms' pursuit of sustainability improvement. Successfully implementing management systems over a long period may also introduce cultural and structural changes of an organization, resulting in higher efficiency gain in firms' pursuit of sustainability goals [55]. Consequently, we assume that:

\section{Hypothesis 4b: There is a "U-shaped" relationship between firm's certification history and an} enhanced efficiency in their pursuit of sustainability.

In summary, certifications may foster effective learning and dynamic capacity development for certified firms to improve their efficiency in pursuing sustainability through four pathways-certification participation, qualitative combination, quantitative expansion, and temporal accumulation [56].

\section{Methods and Data}

\subsection{Sample}

China is famous as the factory to the world, yet it is a late mover in adopting management system certification and corporate social responsibility (CSR). Its sustainability reporting and socially responsible investing (SRI) funds were not officially launched until 2005 and 2008, respectively [57], but have gained momentum since 2009. In the same year, the Chinese Academy of Social Science (CASS) started releasing annual research reports documenting the detailed CSR scores and rankings of the top 300 Chinese firms: 100 multinational corporations, 100 state-owned enterprises, and 100 private companies [58]. Specifically, 73 out of these 300 firms are listed as manufacturing companies [59]. 
To empirically test the hypotheses, we used longitudinal data of these 73 firms from 2009-2012 as 2012 was the latest year with complete firm information when we conducted the data collection in 2014.

This research setting (i.e., the Chinese manufacturing firms) is under-studied in the literature due to a lack of readily-available data. We focused on listed firms since they are required to report their financial, social, and environmental performance data through their webpages and reports, which enabled us to collect archival data for the observations. In recent years, mostly to address stakeholder pressures along the supply chain and to promote cross-border trade, Chinese firms have experienced a significant growth in ISO 9001, ISO 14001, and OHSAS 18001 certification, both in absolute number and percentage of the world's total [14]. The motivations for these firms to certify under these standards are diverse. Many firms have experienced dynamic learning and capacity development during the process. This sample thus provides an important research setting to explore whether certifications actually deliver efficient sustainability outcomes for the certified firms.

In the annual reports, CASS used a comprehensive analytical framework to evaluate selected firms' ability to be financially, environmentally, and socially "responsible", thus resulting in a projection of corporate sustainability performance. We used these annual reports to collect the selected firms' social-environmental data, which include a market performance index (RMI), an environmental performance index (ERI), and a social performance index (SRI). In addition, we retrieved firms' certification data (specifically ISO 9001, ISO 14001, and OHSAS 18001) during 2009-2012 from two governmental agencies: the Certification and Accreditation Administration of the People's Republic of China (CNCA) and the China National Accreditation Service for Conformity Assessment (CNAS). Further, we used the Compustat database and company webpage to collect firm-level attributes such as employee number and total assets.

\subsection{Variables and Measurements for the DEA Model}

Corporate Sustainability Efficiency: We built on economic efficiency [60] and sustainable efficiency [61] concepts to develop an integrative assessment index-Corporate Sustainability Efficiency (CSE). CSE demonstrates a firm's ability in achieving the given sustainability performance (i.e., financial, environmental, and social benefits) with less input composition (i.e., labor, capital, and operational expenses) than its peers in a more productive way. Therefore, CSE reflects a firm's ability to utilize its finite resources through internal management to achieve sustainable outcomes.

In order to determine CSE scores, we reference similar studies and the concept of total-factor production to construct a multi-dimensional evaluation framework. CSE is evaluated using firms' sustainability outputs in financial, social, and environmental performance, against their corresponding operating inputs (labor, capital, and non-production costs). We use employee number, total assets, and selling, general and administrative expenses (SG and A) to measure the inputs of each firm, while financial, environmental, and social outputs are measured by the market performance index (RMI), environmental performance index (ERI), and social performance index (SRI) from the CASS's Annual Research Report from 2010-2013. Here we took a one-year lag to retrieve output data, incorporating time lag for firms to demonstrate performance outcome relate to their inputs. The description of the input and output variables is presented in Table 1. 
Table 1. Description of inputs and output in deriving CSE.

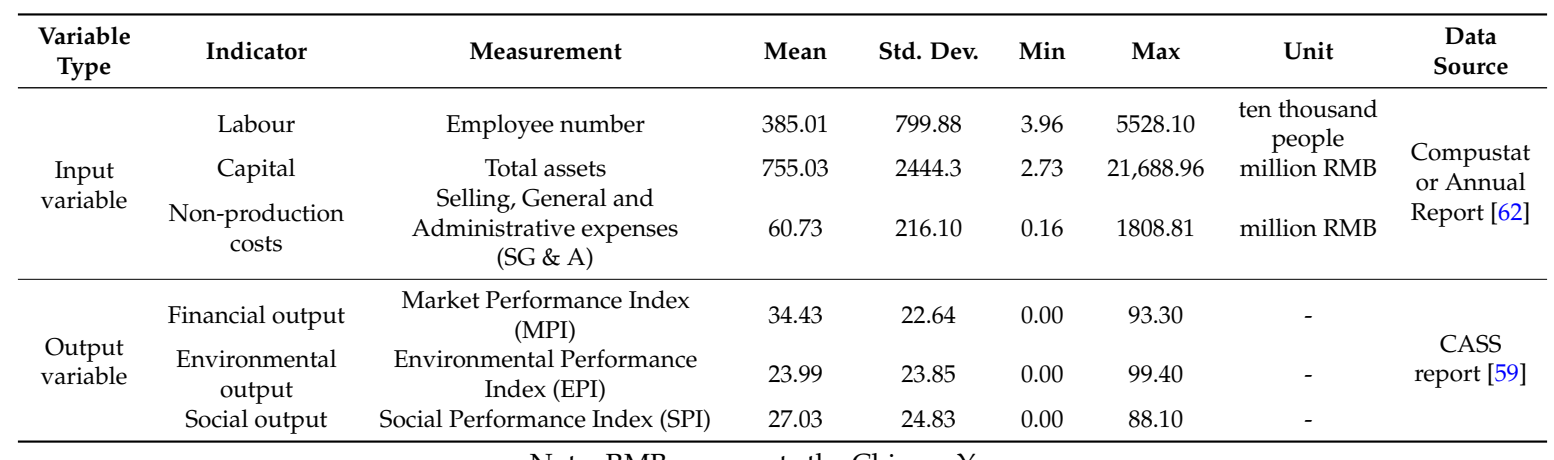

Note: RMB represents the Chinese Yuan.

We further employed a non-parametric linear programming method-data envelopment analysis (DEA) - to derive CSE indexes for the 73 listed firms from the years 2009 to 2012. The DEA approach is based on the concept of the Pareto optimum with the help of linear programming techniques. It is an effective as well as flexible tool for evaluating the relative efficiency of homogeneous subjects (i.e., decision-making units, DMU) with multiple heterogeneous performance measures. It can also avoid the shortcoming of subjective estimates when a priori weighting and aggregating for inputs or outputs are eliminated. Since its introduction in 1978, DEA has become a popular and powerful methodology for estimating relative efficiency among various organizations [63], and has had numerous applications in the environmental and quality management fields [64-66]. Additionally, the epsilon-based measures (EBM) posited by Tone and Tsutsui [67] is considered as one of the most updated DEA techniques, given its ability to combine both radial and non-radial measures in a unified framework.

We, thus, used the EBM approach to obtain the robust CSE for our observations.

Suppose we have $n$ independent homogeneous DMUj, where $\operatorname{DMUj}(j=1,2, \ldots n)$ has $m$ inputs $\left(x_{i j}=x_{1 j}, \ldots, x_{m j}\right)$ and soutputs $\left(y_{r j}=y_{1 j}, \ldots, y_{s j}\right)$. The input and output matrices are denoted by $X=\left\{X_{i j}\right\} \in R^{m \times n}$ and $Y=\left\{Y_{i j}\right\} \in R^{s \times n}$, respectively. For a certain $\mathrm{DMU}_{0}$, its efficiency $\gamma^{*}$ can be estimated using the input-oriented EBM model as below:

$$
\begin{aligned}
& \gamma^{*}=\min \theta-\varepsilon_{x} \sum_{i=1}^{m} \frac{w_{i}^{-} s_{i}^{-}}{x_{0}} \\
& \text { s.t. } \theta x_{0}-X \lambda-s^{-}=0 ; Y \lambda \geqslant y_{0} ; \lambda \geqslant 0, s^{-} \geqslant 0
\end{aligned}
$$

where, $\lambda$ represents the intensity vector and $s^{-}$denotes the non-radial slacks, respectively. Correspondingly, $w^{i}$ is the weight of input $i$ and satisfies $\sum_{i=1}^{m} w_{i}=1$, and $\varepsilon_{x}$ is a key parameter which indicates the relative importance of the non-radial slacks over the radial $\theta$. The CSE score ranges between 0 and 1 , with higher values representing amore efficient level.

We first collect firms' ISO 9001 [68], ISO 14001 [69], or OHSAS 18001 [70] certification data in the years 2009-2012 using three dummies (whether firms specifically have ISO 9001, ISO 14001, or OHSAS 18001). According to the certification data, we categorize firms into three groups: firms with diverse certifications (i.e., with dual- or multiple-types of certification) are classified into category 1 ; firms with homogenous certifications (i.e., either ISO 9001, ISO 14001, or OHSAS 18001) are grouped into category 2; and firms with no certification are included in category 3.

Certification participation. Based on these three categories, firms that fall under either category 1 or 2 are re-grouped as category 4 to represent their certification participation (i.e., cat. $4=$ cat. $1+$ cat.2), while firms without any certificate remain within category 3, otherwise.

Qualitative combination is measured using the category 1 index, indicating diverse certifications (i.e., dual- or multiple-types of certification) certified by one focal firm.

Accordingly, the certification index of certification category 1, 2,3, and 4 in Table 2. 
Table 2. Distributions of management system standards during 2009-2012.

\begin{tabular}{cccccc}
\hline \multirow{2}{*}{ Type } & Explanation & \multicolumn{3}{c}{ Distribution (Number of Firms with Certain Certification) } \\
\cline { 3 - 5 } & & $\mathbf{2 0 0 9}$ & $\mathbf{2 0 1 0}$ & $\mathbf{2 0 1 1}$ & $\mathbf{2 0 1 2}$ \\
\hline ISO 9001 & Certified QMS & 30 & 32 & 39 & 42 \\
ISO 14001 & Certified EMS & 27 & 30 & 35 & 36 \\
OHSAS 18001 & Certified OHS & 13 & 17 & 23 & 29 \\
Category 1 & Firms with diversified certificates & 22 & 26 & 32 & 34 \\
Category 2 & Firm with singular certificate & 15 & 13 & 12 & 10 \\
Category 3 & Firms without certificate & 36 & 34 & 29 & 29 \\
Category 4 & Firms with certificate & $37(=22+15)$ & $39(=26+13)$ & $44(=32+12)$ & $44(=34+10)$ \\
\hline
\end{tabular}

As shown in Table 2, all three certifications have enjoyed steady growth in number of firms certifying under them from 2009 to 2012, with OHSAS 18001 demonstrating the fastest growth rate (1.23 times). For our three categories: firms in category 1 (qualitative combination with two or more diverse certifications) demonstrated a rapid growth rate of 55\% from 2009-2012. Conversely, firms in category 2 (homogeneous certifications) and category 3 (no certification) declined by $33 \%$ and $20 \%$, respectively. These results demonstrate that firms show an increasing tendency to certify and implement diverse types of certification standards during the study period. After 2011, firms with diversified certificates (qualitative combination) dominate firms in category 2 and 3.

\subsection{Statistical Analysis and Results for the DEA Model}

The Wilcoxon rank sum is selected to test Hypothesis 1 and 2 based on the results (i.e., the efficiency scores of the 73 firms during 2009-2012) deriving from the DEA model. Based on the efficiency score calculation through the EBM approach of the 73 firms in the sample we found the following group averages for CSE (refer to Table 3).

Table 3. Group mean of CSE during 2009-2012.

\begin{tabular}{ccccc}
\hline CSE & $\mathbf{2 0 0 9}$ & $\mathbf{2 0 1 0}$ & $\mathbf{2 0 1 1}$ & $\mathbf{2 0 1 2}$ \\
\hline Cat.1 & 0.116 & 0.126 & 0.162 & 0.124 \\
Cat.2 & 0.113 & 0.118 & 0.149 & 0.085 \\
Cat.3 & 0.065 & 0.079 & 0.067 & 0.058 \\
\hline
\end{tabular}

As shown in Table 3, the mean CSE of firms in category 1 (qualitative integration-firms with diverse certifications) was the highest among the three categories in each year from 2009 to 2012, followed by firms in category 2 (firms with homogeneous certifications). Firms in category 3 (firms with no certifications) rank at the bottom.

In order to test Hypothesis 1, we compared the average numbers of CSE for the firms in category 4 (with certification) and category 3 (without certification). To test Hypothesis 2, we compared the average CSE for firms in category 1 (qualitative integration-firms with diverse certificates) and that for firms in category 2 (with singular certificate). Following the studies of [71,72], we used the Wilcoxon rank sum technique, a non-parametric statistical test suitable for small samples, to test the differences in efficiency gaps cross different groups (refer to Table 4).

As shown in Table 4, firms that participated in certification programs (Category 4) were more efficient than firms without any certified management system Moreover, the rank sum test for Hypothesis 1 rejects the null hypothesis that there is no significant difference between the two samples at the $5 \%$ significance level $(p<0.05)$ over time. The findings support Hypothesis 1 , indicating that certified firms tend to have higher CSE than firms without certification. 
Table 4. Efficiency gap among groups.

\begin{tabular}{|c|c|c|c|c|c|c|c|}
\hline \multicolumn{2}{|c|}{$\begin{array}{l}\text { H1: CSE difference } \\
\text { between Firms with } \\
\text { and without } \\
\text { Certification }\end{array}$} & $\begin{array}{l}\text { Cat.4 (Firms } \\
\text { with } \\
\text { Certification) }\end{array}$ & \multirow{2}{*}{$\begin{array}{l}\text { Cat.3 (Firms } \\
\text { with no } \\
\text { Certification) }\end{array}$} & \multicolumn{2}{|c|}{$\begin{array}{l}\text { H2: CSE Difference } \\
\text { between Firms with } \\
\text { Diverse and Singular } \\
\text { Certification }\end{array}$} & $\begin{array}{l}\text { Cat.4 (Firms } \\
\text { with } \\
\text { Certification) }\end{array}$ & \multirow{2}{*}{$\begin{array}{c}\text { Cat.3 (Firms } \\
\text { with no } \\
\text { Certification) }\end{array}$} \\
\hline \multirow{3}{*}{2009} & mean & 0.11 & & 2009 & mean & 0.12 & \\
\hline & rank sum & 1659.5 & 1041.5 & & rank sum & 447 & 256 \\
\hline & Prob. & 0.0 & & & Prob. & \multicolumn{2}{|c|}{0.37} \\
\hline \multirow{3}{*}{2010} & mean & 0.12 & 0.08 & 2010 & mean & 0.13 & 0.12 \\
\hline & rank sum & 1633 & 1068 & & rank sum & 559.5 & 220.5 \\
\hline & Prob. & & & & Prob. & \multicolumn{2}{|c|}{0.24} \\
\hline \multirow{3}{*}{2011} & mean & 0.16 & 0.07 & 2011 & mean & 0.16 & 0.15 \\
\hline & rank sum & 1840 & 861 & & rank sum & 789 & 201 \\
\hline & Prob. & & & & Prob. & \multicolumn{2}{|c|}{$0.07^{*}$} \\
\hline \multirow{3}{*}{2012} & mean & 0.11 & 0.06 & 2012 & mean & 0.12 & 0.08 \\
\hline & rank sum & 1853 & 848.5 & & rank sum & 735 & 255 \\
\hline & Prob. & 0.0 & & & Prob. & \multicolumn{2}{|c|}{0.40} \\
\hline
\end{tabular}

In testing Hypothesis 2, as we expected, the average efficiency level of firms with diverse certification (qualitative integration) outweighed its counterparts in category 2 in all the years. However, the differences between the groups were not significant as the $p$-value during 2009-2012 were all larger than 0.05 . Therefore, while the cross-group CSE comparison shows higher CSE scores for firms with qualitative integration, the effect is only weakly supported in year $2011(B=0.07, p<0.1)$.

\subsection{Variables and Measurements for the Tobit Model}

\subsubsection{Dependent Variable}

The dependent variable in this section is the CSE index of the 73 firms from 2009 to 2012.

\subsubsection{Independent Variables}

Quantitative expansion: Quantitative expansion is measured by adding up the total number of management certification standards certified by all facilities and utilities of a focal firm in a given year, irrespective of the certification type (either ISO 9001, or ISO14001, or OHSAS 18001).

Temporal accumulation: We incorporated two temporal measurements. One is the firm's prior certification experience, which is operationalized by coding whether the focal firm has prior certification experience prior to the current one. We also measure temporal accumulation using certification history, subtracting the year firms received their first certification from the study end year of 2012.

\subsubsection{Control Variables}

Moreover, certain control variables that may affect a firm's CSE have also been integrated into the model, including (1) firm size is measured as the logarithm of a firm's total sales; (2) firm type is a dummy variable measured by whether the focal firm is a multinational company; (3) ownership structure is another dummy variable measured by whether focal firm is a state-owned-enterprise; (4) product type, measured by whether focal firm produces intermediate goods; and (5) business focus, measured by whether focal firm is an export-oriented firm.

We then incorporate a panel regression method to Test Hypothesis 3 (quantitative expansion). Since the dependent variable (the CSE score) is bounded between zero and one, the panel Tobit regression method is identified as the most appropriate method, and is constructed as follows:

$$
\operatorname{cse}_{i, t}^{*}=a+\beta_{1} \text { curr }_{i t}+\beta_{2} h i_{i t}+\beta_{3} h i i_{i t}^{2}+\beta_{4} \exp _{i t}+\beta_{5} s i z e_{i t}+\beta_{6} m n c_{i t}+\beta_{7} s o e_{i t}+\beta_{8} \text { inter } r_{i t}+\beta_{9} \operatorname{export}{ }_{i t}+\varepsilon_{i t}
$$




$$
\operatorname{cse}_{i t}=\max \left(0, c s e_{i t}^{*}\right) ; \varepsilon_{i t} \sim N\left[0, \sigma^{2}\right]
$$

where, $c s e_{i, t}^{*}$ are the latent variables; $c s e_{i, t}$ is the efficiency score of firm $i$ in year $t$; curr $_{i, t}$ denotes the total number of certificates; $h i s_{i, t}$ and $h i s_{i, t}^{2}$ denote firms' certification history and its square number;

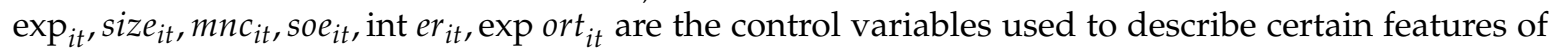
firm $i$ in year $t$., i.e., firm size, firm type, ownership structure, product type, and business focus.

\subsection{Statistical Analysis and Results for the Tobit Model}

Table 5 presents the descriptive analysis of the key variables.

Table 5. Data description for Tobit model.

\begin{tabular}{|c|c|c|c|c|c|c|}
\hline Type & Variables & Operationalization & Mean & Std. Dev. & Min & Max \\
\hline $\begin{array}{l}\text { Dependent } \\
\text { variable }\end{array}$ & CSE & Corporate sustainable efficiency & 0.097 & 0.20 & 0.00 & 1.00 \\
\hline \multirow{4}{*}{$\begin{array}{l}\text { Independent } \\
\text { variables }\end{array}$} & $\begin{array}{l}\text { Quantitative } \\
\text { Expansion }\end{array}$ & Total number of certifications & 1.91 & 2.32 & 0.00 & 13.00 \\
\hline & $\begin{array}{l}\text { Prior certification } \\
\text { experience }\end{array}$ & $\begin{array}{c}\text { Whether a firm has previous } \\
\text { certification history }\end{array}$ & 0.57 & 0.50 & 0.00 & 1.00 \\
\hline & $\begin{array}{c}\text { Temporal } \\
\text { Accumulation }\end{array}$ & $\begin{array}{l}\text { Certification history: initial year } \\
\text { of certification from year } 2012\end{array}$ & 3.08 & 2.97 & 0.00 & 10.00 \\
\hline & $\begin{array}{c}\text { Square of } \\
\text { Temporal } \\
\text { Accumulation }\end{array}$ & Square of "Certification history" & 18.25 & 21.47 & 0.00 & 100.00 \\
\hline \multirow{5}{*}{$\begin{array}{l}\text { Control } \\
\text { Variables }\end{array}$} & Firm size & The logarithm of firms' total sales & 4.97 & 1.81 & 0.19 & 10.22 \\
\hline & $\begin{array}{l}\text { Multinational } \\
\text { corporation }\end{array}$ & $\begin{array}{l}\text { Whether focal firm is a } \\
\text { multinational corporation }\end{array}$ & 0.20 & 0.40 & 0.00 & 1.00 \\
\hline & $\begin{array}{l}\text { State-own } \\
\text { enterprise }\end{array}$ & $\begin{array}{l}\text { Whether focal firm is a } \\
\text { state-owned-enterprise }\end{array}$ & 0.53 & 0.50 & 0.00 & 1.00 \\
\hline & $\begin{array}{l}\text { Immediate good } \\
\text { producer }\end{array}$ & $\begin{array}{l}\text { Whether focal firm produces } \\
\text { immediate good }\end{array}$ & 0.42 & 0.49 & 0.00 & 1.00 \\
\hline & Export-orientation & $\begin{array}{l}\text { Whether focal firm is an } \\
\text { export-oriented firm }\end{array}$ & 0.71 & 0.45 & 0.00 & 1.00 \\
\hline
\end{tabular}

Table 6 presents the results of the Tobit regression model.

Table 6. Panel Tobit Regression Result.

\begin{tabular}{ccc}
\hline & Coef. & $z$ \\
\hline Independent variable & & \\
Quantitative Expansion & $0.413(0.552)$ & 0.750 \\
Prior certification experience & $6.252(3.314)^{*}$ & 1.890 \\
Temporal Accumulation & $-4.126(1.689)^{* *}$ & -2.440 \\
Square of Temporal Accumulation & $0.379(0.171)^{* *}$ & 2.220 \\
Control variable & & -7.910 \\
Firm size & $-7.144(0.904)^{* * *}$ & 1.480 \\
Multinational corporation & $5.323(3.594)$ & 3.510 \\
State-own enterprise & $12.885(3.676)^{* * *}$ & 0.100 \\
Immediate good producer & $0.356(3.698)$ & -1.890 \\
Export-orientation & $-5.324(2.825)^{*}$ & 7.590 \\
cons & $43.735(5.761)^{* * *}$ & Likelihood-ratio $=118.62$ \\
Robust tests for model & Prob $<0.0001$ &
\end{tabular}

Standard errors in parenthesis: significant at ${ }^{* * *} 0.01 ;{ }^{* *} 0.05 ;{ }^{*} 0.1$. 
As shown in Table 6, the panel Tobit regression model is significant at the $1 \%$ significance level $(p=0.000)$. The likelihood-ratio test of sigma also rejected the null hypothesis, indicating the model is significant. While the coefficient of "Quantitative Expansion" was not significant $(p=0.552)$, its sign is positive, as we expected $(B=0.413)$. Therefore, Hypothesis 3 related to quantitative expansion, that is, firms with a greater number of certifications have higher CSE than those with fewer certifications, is not supported by our test.

Our results, however, support Hypothesis $4 \mathrm{a}$, which posits that firms with prior certification experience are associated with higher CSE efficiency gains $(B=6.252, p=0.06)$. Regarding the correlation between CSE and firms" certification history, a notable "U shape" curve appeared as the coefficients of $h i s$ and $h i s^{2}$ were notably negative $(B=-4.126, p=0.015)$ and positive $(B=0.379$, $p=0.027$ ), respectively. Results thus support Hypothesis $4 \mathrm{~b}$, showing that there is a " $\mathrm{U}$ " shape relationship between firms' temporal accumulation and CSE gain. The findings indicate that management system implementation in early years may not endow firms with CSE credits, yet in the long run, the temporal accumulation effect will greatly benefit firms. Relative to the control variables, state-owned companies performed much better than others in terms of sustainable efficiency gains $(B=12.885, p<0.0001)$. Surprisingly, firm size was a key obstacle to efficiency gains throughout the years $(B=-7.144, p<0.0001)$, indicating that being large does not guarantee being efficient. However the export-orientation tends to have influence in firms' CSE gain in certification $(B=-5.324, p=0.059)$. In other words, the impact of export on firm's performance is still ambiguous as many studies have discussed [73,74].

\section{Discussion, Conclusions, and Implication}

Studies in the extant literature tend to individually assess the performance of different standards of management practices from an environment, social, or financial point of view. Using longitudinal data of 73 Chinese-listed manufacturing firms from 2009-2012, our study makes an initial attempt to integrate these three aspects and assess whether and how firms' certification status (e.g., participation, varieties, number, and history) influences their efficiency in pursuit of corporate sustainability goals. Our empirical results confirm that sustainability efficiency gain from certification arises from participation in certification in general, and is further enhanced through qualitative integration (supported in year 2011) and experiential/temporal accumulation.

In conducting the assessment, we advance the management literature by proposing a dynamic capacity view of efficiency gain through certification, highlighting the pathways through which firms enhance efficiency in achieving sustainability goals. These contributions are illustrated below:

First, the extant literature tends to assess the performance of management standard certification from either a financial or an environmental (social) aspect. In contrast, this study integrates the triple-bottom-line goals and assesses certifications from a dynamic efficiency gain aspect. Thus, the study provides a holistic understanding of whether firms achieve higher efficiency in pursuing their sustainability goals by adopting management practice standards (ISO 9001, ISO 14001, and OHSAS 18001). There is intensive debate in the literature regarding the performance of management systems $[2,6,75]$. Prior scholarship questions the sustainability outcome of certification mainly because these management standards focus on infrastructure and process rather than direct performance goals. Our study results inform further debate in this discussion by suggesting that certified firms tend to demonstrate higher sustainable efficiency than firms without certification. This implies that certified firms may gradually transform from "acting green" to "being green". Management standard certification and its followed-up implementation may provide firms a learning and capacity building process, through which certified firms develop greater capacity to improve their efficiency. As such, while it is difficult and costly for firms to have their management systems certified, participating in this process gives firms an advantage over other firms as they respond to stakeholder concerns and address triple-bottom-line issues. Management system certifications remain an effective 
option for firms to pursue corporate sustainability. This insight supports the literature that identifies corporate sustainability as good management embedded in general business strategies practice $[76,77]$.

In addition, our findings indicate that firms improve their efficiency gain as they integrate and integrate diverse management systems. Existing studies on standards of management practices recognize the trend for firms to integrate multiple certifications [40] and emphasize the synergetic benefits associated with bundling and integration [78]. Our study expands this literature by showing that there is an increasing tendency for firms to certify diverse management systems (i.e., with two or three different certifications) and there is an enhanced efficiency gain for firms along the journey.

When comparing the efficiency gain from qualitative integration, we observe an enhancing efficiency gain effect over time: there is no effect in years 2009 and 2010, but the qualitative combination effect started to emerge in 2011. This implies that the qualitative combination efficiency gain may take some time to demonstrate, as firms need substantial time to overcome the difficulties and challenges related to certification integration, such as the lack of human resources, the uncertainties of government support, and the individual concerns of people involved, as well as internal organizational issues like departmentalization of different functions [51]. We suggest that future studies can expand the time frame evaluated in order to investigate our proposed qualitative and quantitative accumulation aspects more closely.

In contrast, there is no efficiency gain for firms conducting quantitative expansion (Hypothesis 3) if they simply copy or repeat the same certification without added values. This counter-intuitive result implies a ceiling effect in certification, that repeating a single certification process and merely expanding in volume offer firms limited additional capacity building in improving their efficiency to pursue sustainability goals. Comparing the results of Hypotheses 2 and 3 seems to support the "high risk, high gain" scenario, that firms may obtain higher efficiency and receive more added value in their certification journey if they make additional effort to combine diverse certifications instead of accumulating the more homogeneous learning effect gained from a single type of certification.

The weak effect in Hypothesis 2 and no effect in Hypothesis 3 could also occurred due to the design of management standard systems. Despite the continual improvement of management standards facilitating firms' efficiency gain, there are still knowledge gaps in these management systems regarding how to integrate the systems to provide the greatest efficiency gains in general corporate performance [79]. The certification process also gives greater attention to the certification itself, neglecting the importance of certification implementation [80]. As such, the design of the systems often fails to fully accommodate firms' dynamic capacity building and simultaneous business performance improvement. Consequently, we assume a higher efficiency gain for certified firms if better standardized management systems provide greater knowledge integrating the systems to corporate general management, and subsequently allow more dynamic capacity building during certification implementation.

Furthermore, our results unpack the nuances of the temporal mechanism of how firms continually enhance efficiency in pursuing sustainability post-certification. We advance the management literature by highlighting the educational effect from firms' prior certification experience, enabling firms to learn from past experience and accumulate capacity to pursue sustainability with higher efficiency. More importantly, our results delineate a " $U$ " shape relationship related to how past certification history is translated into greater efficiency gain; while the temporal accumulation effect may be negative in the short-run, firms may demonstrate stronger learning effects and efficiency gains in the long run.

The results suggest that the enhanced efficiency gains associated with temporal accumulation can only be switched on when firms have a longer certification history. This insight on temporal accumulation endorses an aspect of first-mover advantage, that is, the early adopters may accumulate greater capacity to enhance their efficiency to achieve triple-bottom-line goals than late adopters. Management scholars often suggest it is harder for firms to achieve first-mover advantage through management system adoption, since the benefits of process management practices dissipate in an industry as the majority of firms adopt similar techniques [24]. Our results contradict this scholarship. 
We suggest that while it is harder for early adopters to signal and differentiate themselves in the marketplace, they demonstrate long-term competitive advantages via the temporal accumulation of learning and capacity because early adoption enables firms to embrace sustainability with higher efficiency than late-movers.

Our results have important managerial implications. There is an increasing trend for businesses all over the world to adopt standards of management practices, especially in emerging economies, like China. Knowing that certification remains an efficient approach to pursue sustainability goals, firms may proactively embrace certification as an alternative way to augment their dynamic capabilities.

Specifically, our results highlight a higher efficiency gain for firms with diverse management standards. This outcome encourages firms to adopt a variety of certifications to holistically address different aspects of sustainable issues that exist within an organization. However, considering the difficulties (i.e., require organizational structural change in departmentalization of functions and resources needed to integrate the diverse standards), management should approach this synergetic effect with time and caution.

Management should also readjust their time frame in assessing the outcomes of certification. The greater efficiency gains resulting from firms' certification experience and history may encourage certified firms to allocate sufficient time for trial-and-error experimentation of various certifications, thus allowing firms to gradually accumulate experience that leads to greater long-term efficiency as they address triple-bottom-line responsibilities.

Finally, our empirical assessment enriches the literature by utilizing a typical and critical sample, i.e., the Chinese manufacturing firms, as our study setting. The performance of the Chinese manufacturing sector matters significantly to the worldwide economy and sustainability. Our study has significant implications for Chinese companies that are likely to be relatively new to the concepts and practices of CSR and certification [81]. Chinese firms used to certify for ISO 9001, ISO 14001, and OHAS 18001 merely in response to stakeholder pressures. Our results suggest that no matter what the initial motivation, the benefits of certifications (through participation, qualitative integration, and temporal accumulation) may gradually motivate more firms to embrace certification as a learning opportunity and as an effective approach to simultaneously achieve economic, environmental, and social goals.

Acknowledgments: Financial support for this project was provided by the Social Sciences and Humanities Research Council of Canada (SSHRC) Insight Grant (SSHRC \#435-2012-1557 titled “Cross-Sector Solutions to Complex Environmental issues"), by China National Natural Science Foundation (71272160), China Postdoctoral Science Foundation (2016M591082), and Philosophy Social Sciences Planning Project of Beijing (15JDJGA062).

Author Contributions: Xiaoling Wang conceived of the research, undertook data collection and analysis, and drafted the article. Haiying Lin contributed significantly to the research positioning, design, data collection, result interpretation, and manuscript development. Olaf Weber played important role in proof-reading and revising the article.

Conflicts of Interest: The authors declare no conflict of interest.

\section{References}

1. Jiang, R.J.; Bansal, P. Seeing the need for ISO 14001. J. Manag. Stud. 2003, 40, 1047-1067. [CrossRef]

2. Boiral, O.; Gendron, Y. Sustainable development and certification practices: Lessons learned and prospects. Bus. Strategy Environ. 2011, 20, 331-347. [CrossRef]

3. Gavronski, I.; Paiva, E.L.; Teixeira, R.; de Andrade, M.C.F. ISO 14001 certified plants in Brazil—Taxonomy and practices. J. Clean. Prod. 2013, 39, 32-41. [CrossRef]

4. Potoski, M.; Prakash, A. Covenants with weak swords: ISO 14001 and facilities' environmental performance. J. Policy Anal. Manag. 2005, 24, 745-769. [CrossRef]

5. King, A.A.; Lenox, M.J.; Terlaak, A. The strategic use of decentralized institutions: Exploring certification with the ISO 14001 management standard. Acad. Manag. J. 2005, 48, 1091-1106. [CrossRef]

6. Gomez, A.; Rodriguez, M. The effect of ISO 14001 certification on toxic emissions: An analysis of industrial facilities in the north of Spain. J. Clean. Prod. 2011, 19, 1091-1095. [CrossRef]

7. Boiral, O. Managing with ISO Systems: Lessons from Practice. Long Range Plan. 2011, 44, 197-220. [CrossRef] 
8. Prajogo, D.; Tang, A.K.Y.; Lai, K. Do firms get what they want from ISO 14001 adoption? An Australian perspective. J. Clean. Prod. 2012, 33, 117-126. [CrossRef]

9. Delmas, M. Stakeholders and competitive advantage: The case of ISO 14001. Prod. Oper. Manag. 2001, 10, 343-358. [CrossRef]

10. Darnall, N.; Edwards, J.D. Predicting the cost of environmental management system adoption: The role of capabilities, resources and ownership structure. Strateg. Manag. J. 2006, 27, 301-320. [CrossRef]

11. Terziovski, M.; Power, D.; Sohal, A.S. The longitudinal effects of the ISO 9000 certification process on business performance. Eur. J. Oper. Res. 2003, 146, 580-595. [CrossRef]

12. Welch, E.W.; Rana, S.; Mori, Y. The promises and pitfalls of ISO 14001 for competitiveness and sustainability: A comparison of Japan and the United States. Greener Manag. Int. 2003, 44, 59-73. [CrossRef]

13. Mijatovic, I.S.; Stokic, D. The influence of internal and external codes on CSR practice: The case of companies operating in Serbia. J. Bus. Ethics 2010, 94, 533-552. [CrossRef]

14. Qi, G.; Zeng, S.; Yin, H.; Lin, H. ISO and OHSAS certifications: How stakeholders affect corporate decisions on sustainability. Manag. Decis. 2013, 51, 1983-2005. [CrossRef]

15. Potoski, M.; Prakash, A. Do Voluntary Programs Reduce Pollution? Examining ISO 14001's Effectiveness across Countries. Policy Stud. J. 2013, 41, 273-294. [CrossRef]

16. Petroni, A. Developing a methodology for analysis of benefits and shortcomings of ISO 14001 registration: Lessons from experience of a large machinery manufacturer. J. Clean. Prod. 2001, 9, 351-364. [CrossRef]

17. Poksinska, B.; Eklund, J.; Dahlgaard, J.J. ISO 9001:2000 in small organizations. Lost opportunities, benefits and influencing factors. Int. J. Qual. Reliab. Manag. 2006, 23, 490-512. [CrossRef]

18. Jong, P.; De Paulraj, A.; Blome, C. The Financial Impact of ISO 14001 Certification: Top-Line, Bottom-Line, or Both? J. Bus. Ethics 2014, 119, 131-149. [CrossRef]

19. Nicolau, J.L.; Sellers, R. The stock market's reaction to quality certification: Empirical evidence from Spain. Eur. J. Oper. Res. 2002, 142, 632-641. [CrossRef]

20. Corbett, C.J.; Montes-Sancho, M.J.; Kirsch, D.A. The financial impact of ISO 9000 certification in the United States: An empirical analysis. Manag. Sci. 2005, 51, 1046-1059. [CrossRef]

21. Morris, P.W. ISO 9000 and financial performance in the electronics industry. J. Am. Acad. Bus. 2006, 8, 227-235.

22. Surroca, J.; Tribo, J.A.; Waddock, S. Corporate Responsibility and Financial Performance: The Role of Intangible Resources. Strateg. Manag. J. 2010, 31, 463-490. [CrossRef]

23. Paulraj, A.; de Jong, P. The effect of ISO 14001 certification announcements on stock performance. Int. J. Oper. Prod. Manag. 2011, 31, 765-788. [CrossRef]

24. Benner, M.J.; Veloso, F.M. ISO 9000 practices and financial performance: A technology coherence perspective. J. Oper. Manag. 2008, 26, 611-629. [CrossRef]

25. Naveh, E.; Marcus, A. Achieving competitive advantage through implementing a replicable management standard: Installing and using ISO 9000. J. Oper. Manag. 2005, 24, 1-26. [CrossRef]

26. Comoglio, C.; Botta, S. The use of indicators and the role of environmental management systems for environmental performances improvement: A survey on ISO 14001 certified companies in the automotive sector. J. Clean. Prod. 2012, 20, 92-102. [CrossRef]

27. Potoski, M.; Prakash, A. Green clubs and voluntary governance: ISO 14001 and firms' regulatory compliance. Am. J. Political Sci. 2005, 49, 235-248. [CrossRef]

28. Rao, P.; Hamner, B. Impact of ISO 14000 on Business Performance, Working Paper. Available online: http://www.ibrarian.net/navon/page.jsp?paperid=19775707\&searchTerm=achieve+it (accessed on 19 July 2016).

29. Andrews, R.D. Environmental Management Systems: Do They Improve Performance; University of North Carolina: Chapel Hill, NC, USA, 2003.

30. Robson, L.S.; Clarke, J.A.; Cullen, K.; Bielecky, A.; Severin, C.; Bigelow, P.L.; Irvin, E.; Culyer, A.; Mahood, Q. The effectiveness of occupational health and safety management system interventions: A systematic review. Saf. Sci. 2007, 45, 329-353. [CrossRef]

31. Geibler, J.V. Accounting for the social dimension of sustainability: Experiences from the biotechnology industry. Bus. Strategy Environ. 2006, 15, 334-346. [CrossRef]

32. Teece, D.; Pisano, G.; Shuen, A. Dynamic capabilities and strategic management. Strateg. Manag. J. 1997, 18, 509-533. [CrossRef] 
33. Eisenhardt, K.M.; Martin, J. Dynamic capabilities: What are they? Strateg. Manag. J. 2000, 21, $1105-1121$. [CrossRef]

34. Delmas, M.; Hoffmann, V.H.; Kuss, M. Under the Tip of the Iceberg: Absorptive Capacity, Environmental Strategy, and Competitive Advantage. Bus. Soc. 2011, 50, 116-154. [CrossRef]

35. Zhu, Q.; Cordeiro, J.; Sarkis, J. Institutional pressures, dynamic capabilities and environmental management systems: Investigating the ISO 9000-Environmental management system implementation linkage. J. Environ. Manag. 2013, 114, 232-242. [CrossRef] [PubMed]

36. Aragon-Correa, J.A.; Sharma, S. A contingent resource-based view of proactive corporate environmental strategy. Acad. Manag. Rev. 2003, 28, 71-88.

37. Lopez-Fernandez, M.; Serrano-Bedia, A.M. Organizational Consequences of Implementing an ISO 14001 Environmental Management System: An Empirical Analysis. Organ. Environ. 2007, 20, 440-459. [CrossRef]

38. Zollo, M.; Winter, S.G. Deliberate learning and the evolution of dynamic capabilities. Organ. Sci. 2002, 13, 339-351. [CrossRef]

39. Sakr, D.A.; Sherif, A.; El-Haggar, S.M. Environmental management systems' awareness: An investigation of top 50 contractors in Egypt. J. Clean. Prod. 2010, 18, 210-218. [CrossRef]

40. Zeng, S.X.; Shi, J.J.; Lou, G.X. A synergetic model for implementing an integrated management system: An empirical study in China. J. Clean. Prod. 2007, 15, 1760-1767. [CrossRef]

41. Ioppolo, G.; Cucurachi, S.; Salomone, R.; Saija, G.; Shi, L. Sustainable Local Development and Environmental Governance: A Strategic Planning Experience. Sustainability 2016, 8, 180. [CrossRef]

42. De Oliveira, O.J. Guidelines for the integration of certifiable management systems in industrial companies. J. Clean. Prod. 2013, 57, 124-133. [CrossRef]

43. Martín-peña, M.L.; Díaz-garrido, E.; Sánchez-lópez, J.M. Analysis of bene fits and difficulties associated with firms' Environmental Management Systems: The case of the Spanish automotive industry. J. Clean. Prod. 2014, 70, 220-230. [CrossRef]

44. Tsai, W.-H.; Chou, W.-C. Selecting management systems for sustainable development in SMEs: A novel hybrid model based on DEMATEL, ANP, and ZOGP. Expert Syst. Appl. 2009, 36, 1444-1458. [CrossRef]

45. Simon, A.; Karapetrovic, S.; Casadesus, M. Evolution of Integrated Management Systems in Spanish firms. J. Clean. Prod. 2012, 23, 8-19. [CrossRef]

46. Quazi, H.A.; Khoo, Y.K.; Tan, C.M.; Wong, P.S. Motivation for ISO 14000 certification: Development of a predictive model. Omega 2001, 29, 525-542. [CrossRef]

47. Singh, S. An integrative approach to management systems and business excellence. Afr. J. Bus. Manag. 2011, 5, 1618-1629.

48. López-Fresno, P. Implementation of an integrated management system in an airline: A case study. TQM J. 2010, 22, 629-647.

49. Simon, A.; Yaya, L.H.P. Improving innovation and customer satisfaction through systems integration. Ind. Manag. Data Syst. 2012, 112, 1026-1043. [CrossRef]

50. Gagnier, D.; Smith, T.; Pyle, J. The future of ISO 9000 and ISO 14000. ISO Manag. Syst. 2005, 6, 11-14.

51. Karapetrovic, S.; Casadesus, M.; Heras, I. Dynamics and Integration of Standardized Management Systems: An Empirical Study; Documenta Universitaria: Girona, Spain, 2006.

52. Benner, M.J.; Tushman, M.L. Exploitation, Exploration, and Process Management: The Productivity Dilemma Revisited. Management 2003, 28, 238-256.

53. Jørgensen, T.H. Towards greater sustainable management systems: Through life cycle management and integration. J. Clean. Prod. 2008, 16, 1071-1080. [CrossRef]

54. Fernández, V.; Gutiérrez, L. External managerial networks, strategic flexibility and organizational learning: A comparative study between Non-QM, ISO and TQM firms. Total Qual. Manag. Bus. Excell. 2011, 24, 243-258.

55. Santos, G.; Mendes, F.; Barbosa, J. Certification and integration of management systems: The experience of Portuguese small and medium enterprises. J. Clean. Prod. 2011, 19, 1965-1974. [CrossRef]

56. Tamayo-Torres, J.; Gutierrez-Gutierrez, L.; Ruiz-Moreno, A. The relationship between exploration and exploitation strategies, manufacturing flexibility and organizational learning: An empirical comparison between Non-ISO and ISO certified firms. Eur. J. Oper. Res. 2014, 232, 72-86. [CrossRef]

57. Wang, J.; Qin, S.; Cui, Y.J. Problems and prospects of CSR system development in China. Int. J. Bus. Manag. 2010, 5, 128-134. [CrossRef] 
58. Chinese Academy of Social Science. The Research Report on Corporate Social Responsibility of China 2009 (i.e., 2009 Blue Book on Chinese Corporate Social Responsibility); Social Sciences Academic Press: Beijing, China, 2009.

59. Chinese Academy of Social Science. The Research Report on Corporate Social Responsibility of China 2009 (i.e., 2009 Blue Book on Chinese Corporate Social Responsibility); Social Sciences Academic Press: Beijing, China, 2012.

60. Farrell, M.J. The Measurement of Productive Efficiency. J. R. Stat. Soc. Ser. A 1957, 120, 253-290. [CrossRef]

61. Hoang, V.N.; Rao, D.S.P. Measuring and decomposing sustainable efficiency in agricultural production: A cumulative exergy balance approach. Ecol. Econ. 2010, 69, 1765-1776. [CrossRef]

62. Standard \& Poor. Compustat Database_Global. Avaiable online: http://www.compustat.com (accessed on 19 July 2016).

63. Emrouznejad, A.; Parker, B.R.; Tavares, G. Evaluation of research in efficiency and productivity: A survey and analysis of the first 30 years of scholarly literature in DEA. Socio-Econ. Plan. Sci. 2008, 42, 151-157. [CrossRef]

64. Lee, K.H.; Farzipoor, S.R. Measuring corporate sustainability management: A data envelopment analysis approach. Int. J. Prod. Econ. 2012, 140, 219-226. [CrossRef]

65. Sueyoshi, T.; Goto, M.; Ueno, T. Performance analysis of U.S. coal-fired power plants by measuring three DEA efficiencies. Energy Policy 2010, 38, 1675-1688. [CrossRef]

66. Schoenherr, T.; Talluri, S. Environmental Sustainability Initiatives: A Comparative Analysis of Plant Efficiencies in Europe and the U.S. IEEE Trans. Eng. Manag. 2013, 60, 353-365. [CrossRef]

67. Tone, K.; Tsutsui, M. An epsilon-based measure of efficiency in DEA-A third pole of technical efficiency. Eur. J. Oper. Res. 2010, 207, 1554-1563. [CrossRef]

68. International Standard Organization. Reaping the benefits of ISO 9001. Available online: http://www.iso.org/ iso/publication_item.html?pid=PUB100369 (accessed on 19 July 2016).

69. International Standard Organization. ISO 14001-Key benefits. Available online: http://www.iso.org/iso/ publication_item.html?pid=PUB100372 (accessed on 19 July 2016).

70. British Standards Institution. The Health and Safety \& OHSAS Guide. Available online: http://www.ohsas18001-occupational-health-and-safety.com/ (accessed on 19 July 2016).

71. Joo, S.J.; Min, H.; Kwon, I.G.; Kwon, H. Comparative efficiencies of specialty coffee retailers from the perspectives of socially responsible global sourcing. Int. J. Logist. Manag. 2010, 21, 490-509. [CrossRef]

72. Vitaliano, D.F.; Stella, G.P. The cost of corporate Social Responsibility: The case of the Community Reinvestment Act. J. Prod. Anal. 2006, 26, 235-244. [CrossRef]

73. Bernard, A.B.; Jensen, J.B. Exceptional exporter performance: Cause, effect, or both? J. Int. Econ. 1999, 47, 1-25. [CrossRef]

74. Lu, J.; Lu, Y.; Tao, Z. Pure Exporter: Theory and Evidence from China. World Econ. 2014, 37, 1219-1236. [CrossRef]

75. Ioppolo, G.; Salomone, R.; Saija, G. Developing a Territory Balanced Scorecard approach to manage projects for local development: Two case studies. Land Use Policy 2012, 29, 629-640. [CrossRef]

76. Adams, C.A.; Frost, G.R. Integrating sustainability reporting into management practices. Account. Forum 2008, 32, 288-302. [CrossRef]

77. Schaltegger, S.; Wagner, M. Integrative management of sustainability performance, measurement and reporting. Int. J. Account. Audit. Perform. Eval. 2006, 3, 1-19. [CrossRef]

78. Pun, K.F.; Hui, I.K. Integrating the safety dimension into quality management systems: A process model. Total Qual. Manag. 2002, 13, 373-391. [CrossRef]

79. Hamschmidt, J.; Dyllick, T. ISO 14001. Greener Manag. Int. 2001, 34, 43-54. [CrossRef]

80. Weber, O. Factors Influencing the Implementation of Environmental Management Systems, Practices and Performance. In Strategic Sustainability: The State of the Art in Corporate Environmental Management Systems; Sroufe, R., Sarkis, J., Eds.; Greenleaf: Sheffield, UK, 2007; pp. 190-204.

81. Weber, O. Environmental, Social and Governance Reporting in China. Bus. Strategy Environ. 2014, 23, 303-317. [CrossRef]

(C) 2016 by the authors; licensee MDPI, Basel, Switzerland. This article is an open access article distributed under the terms and conditions of the Creative Commons Attribution (CC-BY) license (http:/ / creativecommons.org/licenses/by/4.0/). 